\title{
Isolation, characterization and optimization of bacterial isolate SARR1 for biodegradation of pretreated low density polyethylene
}

\author{
Ritu Rani \\ Department of Microbiology, Maharshi Dayanand University, Rohtak-124001 (Haryana), India \\ Jitender \\ Department of Microbiology, Maharshi Dayanand University, Rohtak-124001 (Haryana), India \\ Nater Pal Singh \\ Centre for Biotechnology, Maharshi Dayanand University, Rohtak-124001 (Haryana), India \\ Anita Rani Santal* \\ Department of Microbiology, Maharshi Dayanand University, Rohtak-124001 (Haryana), India \\ *Corresponding author: Email: anita.micro@mdurohtak.ac.in
}

\section{Article Info}

https://doi.org/10.31018/ jans.v13i2.2663

Received: April 5, 2021

Revised: May 17, 2021

Accepted: May 20, 2021

\section{How to Cite}

Rani, R. et al. (2021). Isolation, characterization and optimization of bacterial isolate SARR1 for biodegradation of pretreated low density polyethylene. Journal of Applied and Natural Science, 13(2), 561 - 570. https://doi.org/10.31018/jans.v13i2.2663

\begin{abstract}
Accumulation of low-density polyethylene (LDPE) has caused a threat to the environment because of its stable and inert nature as it cannot be degraded easily by microorganisms. Its lightweight, low cost, strength, durability, and its various other applications, have led to the wide usage of the polymer, which is exerting a negative effect on both marine and land biota. The development of an eco-friendly or a promising strategy is needed to reduce LDPE waste from both land and water. In the present study, observations have been made to isolate highly efficient LDPE degrading bacteria. The response surface methodology (RSM) was used to predict the best optimization of media for the degradation of LDPE by isolate SARR1. The isolate SARR1 was selected through primary screening by weight loss method and secondary screening using $\mathrm{CO}_{2}$ evolution test, TTC and MATH Test. The isolate SARR1 showed $6.30 \pm 0.25 \mathrm{~g} / \mathrm{L} \mathrm{CO}$ evolution. The microbial adhesion hydrophobicity (MATH) was observed during log phase (100 to $56.89 \pm 0.97 \%$ ) and stationary phase (100 to $82.92 \pm 1.24 \%)$. An isolate SARR1 converted the TTC into red coloured insoluble triphenyl formazan (TPF) after incubation of 7 days. The isolated bacteria SARR 1 showed $38.3 \pm 1.27 \%$ biodegradation efficiency in the pretreated LDPE strips at $37^{\circ} \mathrm{C}$ and $\mathrm{pH} 7.0$ under optimized conditions within 30 days of incubation. This bioremediation and biodegradation approach is eco-friendly and safe for the environment. The results of treatment with isolate SARR1 had a potential hope to degrade LDPE at higher rate than natural degradation.
\end{abstract}

Keywords: Biodegradation, Bioremediation, Durability, Eco-friendly, LDPE, Bacteria

\section{INTRODUCTION}

Plastics are non-biodegradable and a potential xenobiotic compound that can cause impact globally (Ghosh et al., 2019). The wide use of low-density polyethylene (LDPE) is increasing day by day because of its applications in pharmaceuticals industries, agriculture, households, and food packaging industries and due to its inert and durable nature (Erni-Cassola et al., 2019). Out of total waste generated, LDPE contributes about $60-80$ $\%$ of waste to the marine environment (Iniguez et al., 2019). The remaining of the generated enters into the landfills and remains undegraded for a longer duration (Hahladakis and lacovidou, 2019). The most significant ecological threat is its slow degradation rate or non- biodegradability in nature (Emadian et al., 2017) as it is resistant to microbial degradation (Tokiwa et al., 2009). Oxidative degradation of polyethylene releases harmful chemicals that have negative effects on the environment (Sojak et al., 2006). CPCB reports of the year 2017-18 estimates that India on an average generates 9.4 million tonnes of plastic wastes per annum which is approximately 26000 tonnes of plastic wastes per day and out of these 9.4 million tonnes of waste, only 5.6 million tonnes of plastic wastes are recycled per annum and the remaining 3.8 million tones left unchecked and littered. Degradation of plastic is difficult because of its stable nature and the basic sources responsible for the increase in its pollution are increasing population, changes in lifestyle, improper recycling, improper dis- 
posal, and waste management systems (Balestri et al., 2019). Improper handling of LDPE wastes is a threat to marine biota and the birds consuming it, intake of it blocks the intestines of fishes and decrease their gastric secretions, reduced food intake, affects the level of the hormones and increases reproductive failure chances and ultimately leads to their death (Azzarello and Van Vleet,1987). In recent years, a great emphasis is being led on screening potential microorganisms that can degrade LDPE and would help in the proper management of the littered waste (Skariyachan et al., 2016, Idowu et al., 2019). Studies have also shown LDPE as a possible substrate for heterotrophic microorganisms, which can breakdown these polymers under optimized conditions (Pathak and Kumar, 2017). These microbes release certain intracellular and extracellular enzymes which can break the bonds in LDPE. Both bacteria and fungi play a vital role in polyethylene degradation by natural metabolic mechanisms. The degradation of polyethylene begins with the attachment of microbes to the LDPE surface (Jamal et al., 2018). In this study, an efficient bacterial strain SARR1 was isolated from the LDPE dumping site of Haryana, India, and its LDPE degradation potential was studied. The scope of the study is to isolate and identify potential microorganisms that can easily degrade LDPE, where biodegradation serves as a promising tool for elimination of the plastic and polyethylene wastes from the environment.

\section{MATERIALS AND METHODS}

\section{LDPE and bacterial cultures}

LDPE strips $(40 \mu$ and size of $3 \times 3 \mathrm{~cm})$ were purchased from the local market of Rohtak, Haryana, India. The strips were sterilized using $75 \%$ ethanol and then airdried. The bacteria were isolated from the soil collected from the municipal wastes dumping sites of Ismailabad, Pehowa (Haryana) India. The sample was collected in a sterilized zip lock bags.

\section{Media used}

The mineral salt (MS) media (yeast extract $0.002 \%$, $\mathrm{KCl} 0.05 \%, \mathrm{~K}_{2} \mathrm{HPO}_{4} 0.12 \%, \mathrm{MgSO}_{4} .7 \mathrm{H}_{2} \mathrm{O} 0.05 \%$, $\mathrm{CaCl}_{2} .2 \mathrm{H}_{2} \mathrm{O} 0.01 \%, \mathrm{NaNO}_{3} 0.3 \%, \mathrm{KH}_{2} \mathrm{PO}_{4} 0.014 \%$, and $\mathrm{Fe}\left(\mathrm{SO}_{4}\right)_{3} 0.001 \%$ amended with LDPE strips) was used for the cultivation of bacteria. To solidify the media, agar $(2 \%)$ was added and sterilized at $121{ }^{\circ} \mathrm{C}$ at 15psi for 15 min (Skariyachan et al., 2016, Das and Kumar, 2015).

\section{Isolation of potential bacterial isolates}

The isolation of bacteria was done using the enrichment culture technique (Yang et al., 2004). $10 \mathrm{~g}$ of soil sample was suspended in $90 \mathrm{~mL}$ of $\mathrm{MS}$ broth media amended with LDPE strips and incubated for 30 days at $37^{\circ} \mathrm{C}$ under static conditions. After incubation $100 \mu \mathrm{L}$ inoculums were spread on agar plates and further purified by streak plate method (Skariyachan et al., 2016, Das and Kumar, 2015). The isolated culture would be submitted at National Centre for Cell Science (NCCS), Pune and is under process.

\section{Screening of isolates}

The primary and secondary screening methods were followed for the selection of promising bacterial isolates.

\section{Primary screening}

The primary screening was done by using the weight loss method of LDPE (Bardaji et al., 2019). After the bacterial treatment, the strips were thoroughly washed with $2 \% \operatorname{SDS}(\mathrm{v} / \mathrm{v})$ followed by distilled water, and dried overnight at room temperature. The degradation capability was calculated by the following formula (Sarker et al., 2020).

$$
\% \text { Degradation of LDPE }=\frac{\mathrm{I}_{\mathrm{w}}-\mathrm{F}_{\mathrm{w}}}{\mathrm{I}_{\mathrm{w}}} \times 100
$$

Where,

$I_{w}$ is the initial weight of the LDPE strip before bacterial treatment and $F_{w}$ is the final weight of the LDPE strip after 30 days of bacterial treatment.

\section{Secondary screening}

After the primary screening, secondary screening was done to confirm the degradation of LDPE by the isolated bacteria using different types of polyethylene biodegradability tests, i.e. Sturm test $\left(\mathrm{CO}_{2}\right.$ evolution) (Esmaeili et al., 2013), triphenyl tetrazolium chloride (TTC) test (Wolinska et al., 2016, Kumari et al., 2019), and microbial adhesion to hydrocarbons test (MATH) (Vague et al., 2019).

\section{Sturm test}

This test was used to monitor the $\mathrm{CO}_{2}$ evolution in the biometric flasks designed for aerobic biodegradation of LDPE. The amount of $\mathrm{CO}_{2}$ evolved was determined by employing the titration method (Esmaeili et al., 2013, Mohee and Unmar, 2007).

\section{Triphenyl tetrazolium chloride (TTC) test}

The bacterial isolate SARR1 showed highest $\mathrm{CO}_{2}$ evolution in the Sturm test was selected for the TTC test. The 2, 3, 5-triphenyl tetrazolium chloride was used as a redox probe which indicates the capability and metabolic activity of the surface-adhered bacteria. $40 \mu \mathrm{L}$ of 1.0 $\%$ TTC solution was added in autoclaved $20 \mathrm{~mL}$ MS media inoculated with isolate SARR1 and incubated for 7 days in dark conditions (Kumari et al., 2019).

Microbial adhesion to hydrocarbons test (MATH) The microbial adhesion capability on LDPE strips sur- 
face was analyzed by using this method (Gilan et al., 2004, Sarkar et al., 2020). The LDPE strip was inoculated with the isolate SARR1 in mineral salt broth media and incubated at $37^{\circ} \mathrm{C}$ for 30 days under static conditions. $1.5 \mathrm{~mL}$ bacterial suspension was pooled at the different time intervals of growth phases. Different volumes of hexadecane $(0.5 \mathrm{~mL}-4 \mathrm{~mL})$ were added to each pooled sample and vortexed for $2 \mathrm{~min}$. and incubated at room temperature for $2 \mathrm{~min}$. for the separation of the organic phase and aqueous phase. The optical density of the aqueous phase was measured using a UV visible spectrophotometer at $600 \mathrm{~nm}$.

\section{Morphological and biochemical characterization of LDPE degrading bacteria}

The morphological, microscopic, and biochemical characterization of isolate SARR1 was done using the standard protocols of Bergey's manual (Whitman et al., 1984).

\section{Optimization of media with RSM}

With the help of the response surface methodology, the growth conditions and \% degradation of LDPE were optimized. Results were analyzed by using the software, Design-Expert version 13.0 (Stat-Ease Inc. Minneapolis, USA). The parameters optimized were $\mathrm{pH}$, temperature, carbon source and nitrogen source (Table 1). The CCD (Central composite design) was employed and experimental design was obtained. The quadratic model was used to analyze the data. This particular model was best suited for the data with several constants in their model and also interprets interaction of the growth parameters with the variables.

\section{LDPE pre-treatment using physical and chemical methods \\ Ultraviolet irradiation treatment to LDPE}

The LDPE films were irradiated for 30 days under UV light in an ultraviolet chamber. The LDPE films were cut into strips $(3 \times 3 \mathrm{~cm})$ for biodegradation study (Esmaeili et al., 2013).

\section{Heat treatment to LDPE}

UV treated LDPE strips were placed at temperature 70 ${ }^{\circ} \mathrm{C}$ in a hot-air oven for a maximum of 30 days (Mourad, 2010)

\section{Chemical treatment and biological treatment to LDPE strips}

After both UV and heat treatments to the LDPE strips, these were further treated with concentrated nitric acid (99.9\%) for 10 days. The strips were removed, rinsed with sterile distilled water and then rinsed with $70 \%$ ethanol for $30 \mathrm{~min}$. The strips were oven dried overnight at $45{ }^{\circ} \mathrm{C}$ to $50{ }^{\circ} \mathrm{C}$ and measured their weight (Hasan et al., 2007). After physical and chemical treat- ment to LDPE strips, biological treatment with isolate SARR1 was performed. The isolate SARR1 was inoculated in sterile MS broth media amended with pretreated LDPE strip and incubated for 30 days at $37^{\circ} \mathrm{C}$. After incubation, the biodegradation percentage was calculated using the weight-loss method.

\section{Statistical analysis}

The data was represented by a combination of average mean and standard deviation (mean $\pm S D$ ). For the study of low-density polyethylene degradation, all the experiments were performed in triplicates. ANOVA (Analysis of Variance) was also carried out to determine the fit mechanism of the quadratic model.

\section{RESULTS AND DISCUSSION}

\section{Isolation and primary screening of LDPE degrading bacteria}

Five bacterial cultures were isolated from the soil samples of the waste disposal site. After the primary screening, based on the weight loss method of LDPE, the isolate SARR1 was observed as the most efficient strain for LDPE degradation (Fig. 1A). Bacterial cultures Bacillus amyloliquefaciens strain BSM-1 and strain BSM-2 have shown LDPE weight loss of $11.0 \%$ and $16.0 \%$, respectively, within 60 days of incubation (Das and Kumar, 2015, Harshvardhan and Jha, 2013, Bhatia et al., 2014). Pseudomonas aeruginosa strain SKN1 and strain SKN2 also showed LDPE weight loss of $10.32 \%$ within 60 days of incubation (Nourollahi et al., 2019). In contrast to these studies, the bacterial isolate SARR1 was the most efficient strain that showed the biodegradation activity of $28.12 \pm 1.09 \%$ within 30 days of incubation only.

\section{Secondary screening}

\section{Sturm Test $\left(\mathrm{CO}_{2}\right.$ evolution test)}

The isolate SARR1 showed $6.30 \pm 0.25 \mathrm{gL}^{-1} \mathrm{CO}_{2}$ evolutions (Fig. 1B). The isolate SARR1 showed maximum $\mathrm{CO}_{2}$ evolution and biodegradation activity. The fungal isolates $A$. clavatus and Fusarium sp. showed $\mathrm{CO}_{2}$ evolution of $2.32 \mathrm{gL}^{-1}$ and $1.85 \mathrm{gL}^{-1}$, respectively (Shah et al., 2008, Gajendiran et al., 2016).

\section{Triphenyl tetrazolium chloride (TTC) test}

The TTC was reduced to red-colored insoluble triphenylformazan by the isolate SARR1 after incubation of 7 days (Fig. 1C). The viability and metabolic activities of the surface attached bacteria were observed with the production of triphenylformazan, which facilitates the direct monitoring of active respiration of SARR1. In the same way, Kocuria palustris M16, $B$. pumilus M27, and B. subtilis $\mathrm{H} 1584$ also showed positive viability test with TTC (Harshvardhan and Jha, 2013). The bacterium Bacillus sp. strain AlIW2 reduces 
TTC proved the LDPE degradation (Kumari et al., 2019).

\section{Microbial adhesion to hydrocarbons (MATH) test} MATH test resulted that the bacterial isolate SARR1 was hydrophobic at different concentrations of hexadecane (0 to $4 \mathrm{~mL}$ ). The \% O.D. was decreased from 100 to $56.89 \pm 0.97 \%$ during the log phase as the concentration of hexadecane increased (Fig. 1D). Under stationary phase, turbidity was decreased from 100 to $82.92 \pm 1.24 \%$. Rhodococcus ruber strain C208, C332, B334, and E478 showed maximum hydrophobicity at a very low concentration of hexadecane, and Rhodococcus ruber strain C208 showed $20 \%$ reduction in the turbidity (Gilan et al., 2004). A significant increase $(32.0 \%)$ in the hydrophobicity of $K$. palustris and $B$. subtilis has earlier been reported (Harshvardhan and Jha, 2013, Mukherjee et al., 2016.

Morphological, physiological, and biochemical

Table 1. Parameters for RSM optimization for the \% Degradation.

\begin{tabular}{lllllllllll}
\hline Factor & Name & Units & Type & $\begin{array}{l}\text { Sub } \\
\text { Type }\end{array}$ & Minimum & Maximum & Coded Low & Coded High & Mean & Std. Dev. \\
\hline A & $\mathrm{pH}$ & Numeric & $\begin{array}{l}\text { Continu- } \\
\text { ous }\end{array}$ & 3.00 & 11.00 & $-1 \leftrightarrow 3.00$ & $+1 \leftrightarrow 11.00$ & 7.00 & 3.14 & \\
B & $\begin{array}{l}\text { Temper- } \\
\text { ature }\end{array}$ & ${ }^{\circ} \mathrm{C}$ & Numeric & $\begin{array}{l}\text { Continu- } \\
\text { ous }\end{array}$ & -5.00 & 55.00 & $-1 \leftrightarrow 15.00$ & $+1 \leftrightarrow 55.00$ & 33.52 & 17.48 \\
$\mathrm{C}$ & Carbon & $\mathrm{g}$ & Numeric & $\begin{array}{l}\text { Continu- } \\
\text { ous }\end{array}$ & 0.0000 & 4.00 & $-1 \leftrightarrow 1.00$ & $+1 \leftrightarrow 3.00$ & 2.00 & 0.9608 \\
$\mathrm{D}$ & Nitrogen & $\mathrm{g}$ & Numeric & $\begin{array}{l}\text { Continu- } \\
\text { ous }\end{array}$ & 0.5000 & 2.50 & $-1 \leftrightarrow 1.00$ & $+1 \leftrightarrow 2.00$ & 1.50 & 0.4804 \\
\hline
\end{tabular}
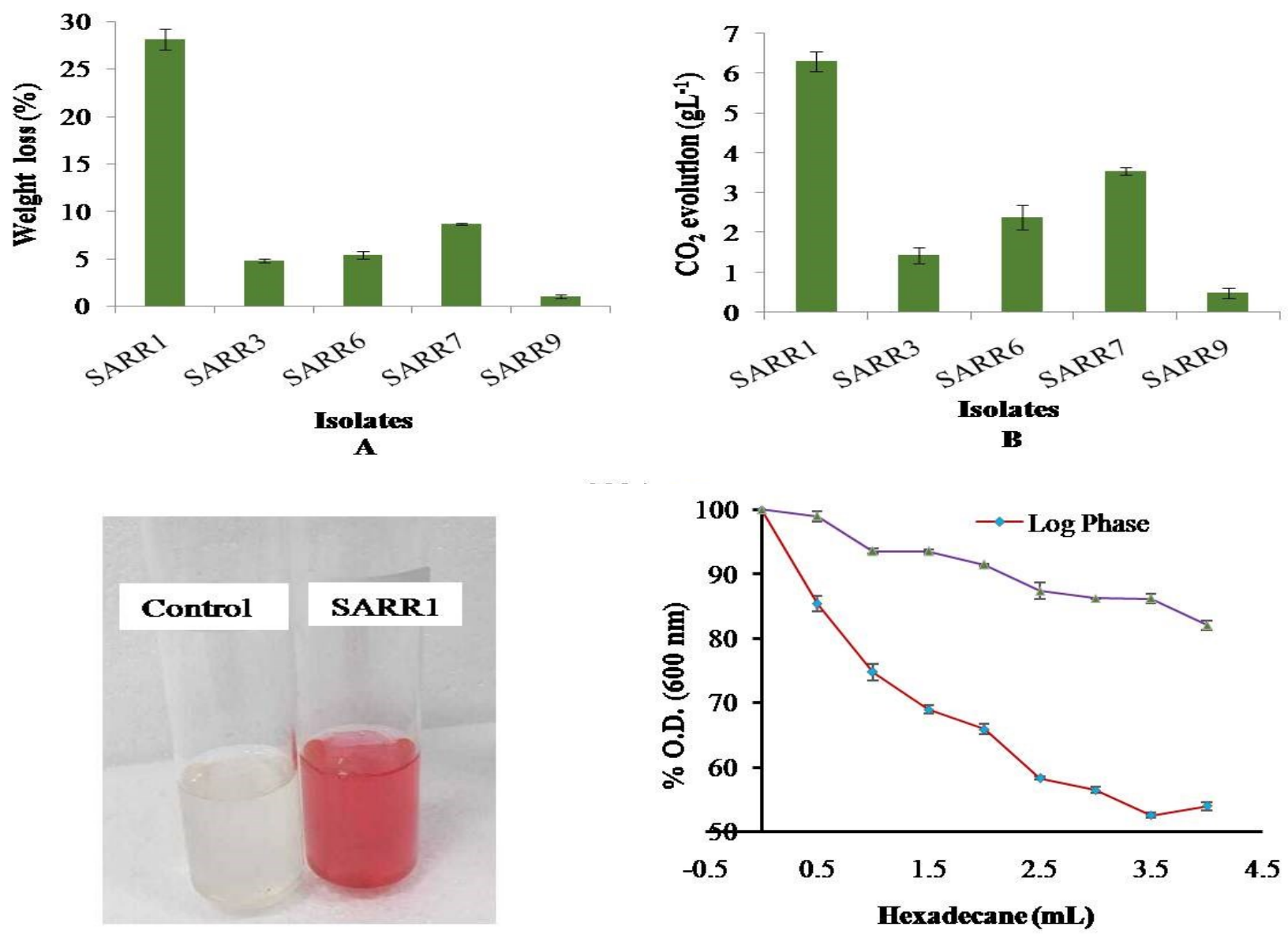

$\mathbf{C}$

D

Fig.1. (A) Primary screening of LDPE degrading bacterial isolates on the basis of weight loss method. Secondary screening of LDPE degrading bacterial isolates on the basis of (B) Sturm test (C) TTC test (D) MATH test. 
Rani, R. et al. / J. Appl. \& Nat. Sci. 13(2), 561 - 570 (2021)

Table 2. Morphological, microscopic, physiological, and biochemical characterization of the isolate SARR1.

\begin{tabular}{lll}
\hline A & Morphological and microscopic characterizations \\
\hline 1 & Configuration & Round \\
2 & Margin & Entire \\
3 & Elevation & Convex \\
4 & Surface & Smooth \\
5 & Color & Cream \\
6 & Cell shape & Rods \\
7 & Gram's reaction & + \\
8 & Endospore staining & + \\
9 & Capsule staining & - \\
\hline B & Physiological characterization & \\
\hline I & Growth at temperatures & \\
1 & $4{ }^{\circ} \mathrm{C}$ & - \\
2 & $28{ }^{\circ} \mathrm{C}$ & $(+)$ \\
3 & $37{ }^{\circ} \mathrm{C}$ & + \\
4 & $45{ }^{\circ} \mathrm{C}$ & $(+)$ \\
5 & $50{ }^{\circ} \mathrm{C}$ & $(+)$ \\
II & Growth at pH & \\
1 & $\mathrm{pH} 3$ & - \\
2 & $\mathrm{pH} 5$ & $(+)$ \\
3 & $\mathrm{pH} 7$ & + \\
4 & $\mathrm{pH} 9$ & $(+)$ \\
5 & $\mathrm{pH} 11$ & - \\
\hline & &
\end{tabular}

\begin{tabular}{lll} 
C & Biochemical characterization & \\
\hline 1 & Nitrate reduction test & - \\
2 & Oxidase test & + \\
3 & Catalase test & - \\
4 & Citrate utilization & + \\
5 & Urea hydrolysis & - \\
6 & Indole test & - \\
7 & Methyl red & - \\
8 & Voges Proskauer's & - \\
9 & Indole production & - \\
10 & Urea hydrolysis & - \\
\hline
\end{tabular}

\section{characterization of isolate SARR1}

The colonies of isolate SARR1 were spherical, convex, and cream in colour. The isolate SARR1 was grampositive, rod-shaped, and endospore-forming bacteria. The maximum growth of the isolate SARR1 was at 37 ${ }^{\circ} \mathrm{C}$ at $\mathrm{pH}$ 7. Biochemical characterization resulted in a positive oxidase and citrate utilization test while other tests were negative (Table 2). The bacteria can be identified using biochemical tests because each bacterium has slightly different metabolic properties (Eslami et al., 2019).

Pre-treatment of LDPE using physical, chemical, and biological methods

The sequential pre-treatments of LDPE strips using physical and chemical methods were also monitored
Table 3. Experimental Design by RSM.

\begin{tabular}{llll}
\hline $\begin{array}{l}\text { File Ver- } \\
\text { sion }\end{array}$ & $\mathbf{1 3 . 0 . 3 . 0}$ & & \\
\hline Study Type & $\begin{array}{l}\text { Response } \\
\text { Surface }\end{array}$ & Subtype & $\begin{array}{l}\text { Random- } \\
\text { ized }\end{array}$ \\
$\begin{array}{l}\text { Design } \\
\begin{array}{l}\text { Type } \\
\text { Design }\end{array}\end{array}$ & $\begin{array}{l}\text { Central Com- } \\
\text { posite }\end{array}$ & Runs & 27.00 \\
$\begin{array}{l}\text { model } \\
\text { Build Time } \\
\text { (ms) }\end{array}$ & Quadratic & Blocks & No blocks \\
\hline
\end{tabular}

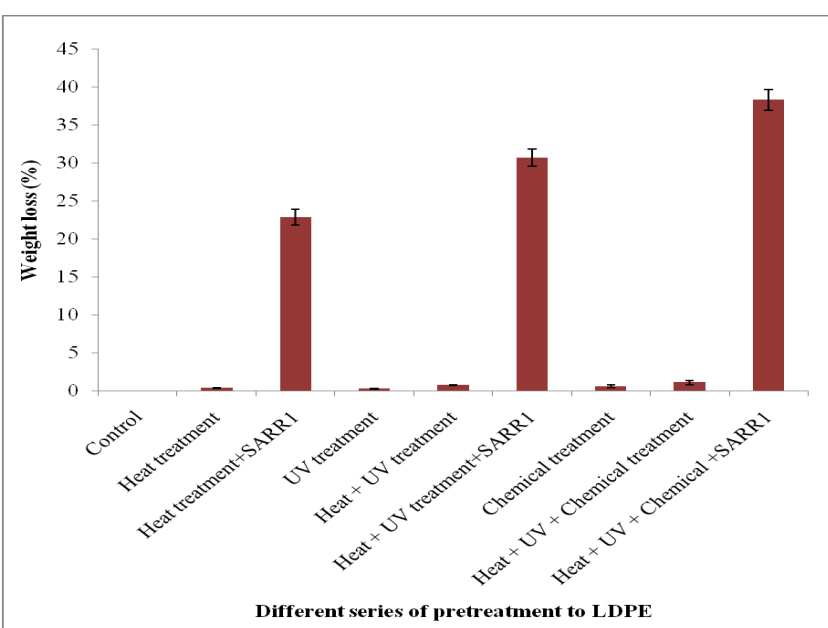

Fig. 2. Effect of different pretreatment methods (UV treatment, heat treatment and chemical treatment) on the degradation of the LDPE and enhanced biodegradation of pretreated LDPE by an isolate SARR1.

before biological LDPE degradation. After heat treatment, $0.35 \pm 0.07 \%$ weight loss of LDPE strips was recorded followed by $22.85 \pm 2.28 \%$ weight loss with isolate SARR1 under optimized conditions. Both the heat and UV treatment showed a $0.75 \pm 0.21 \%$ weight loss followed by $30.67 \pm 1.15 \%$ of LDPE weight loss with isolated SARR1. After heat and UV treatment, chemical treatment to the pretreated LDPE strips showed a weight loss of $1.09 \pm 0.16 \%$ and the isolate SARR1 further degraded the LDPE strip to $38.31 \pm$ $1.27 \%$ (Fig. 2). Similarly, B. amyloliquefaciens showed $0.5-1.3 \%$ degradation on the pre-heat-treated LDPE and LLDPE strips (Novotný et al., 2018). Similarly, $B$. borstelensis showed $25 \%$ more degradation after pretreated ultraviolet irradiated LDPE (Hadad et al., 2005).

\section{Response model of prediction}

The 3D response surface plot was generated by using OVAT and the relationship between the variables and response was optimized through Three-dimensional (3D) response surface or contour plot analysis to check the effect of $\mathrm{pH}$, temperature, carbon source and temperature on the degradation of LDPE by SARR1 (Table 1, 3; Fig. 3). The values of ANOVA (Table 4) were suggested that the model developed and represented be- 
Rani, R. et al. / J. Appl. \& Nat. Sci. 13(2), 561 - 570 (2021)

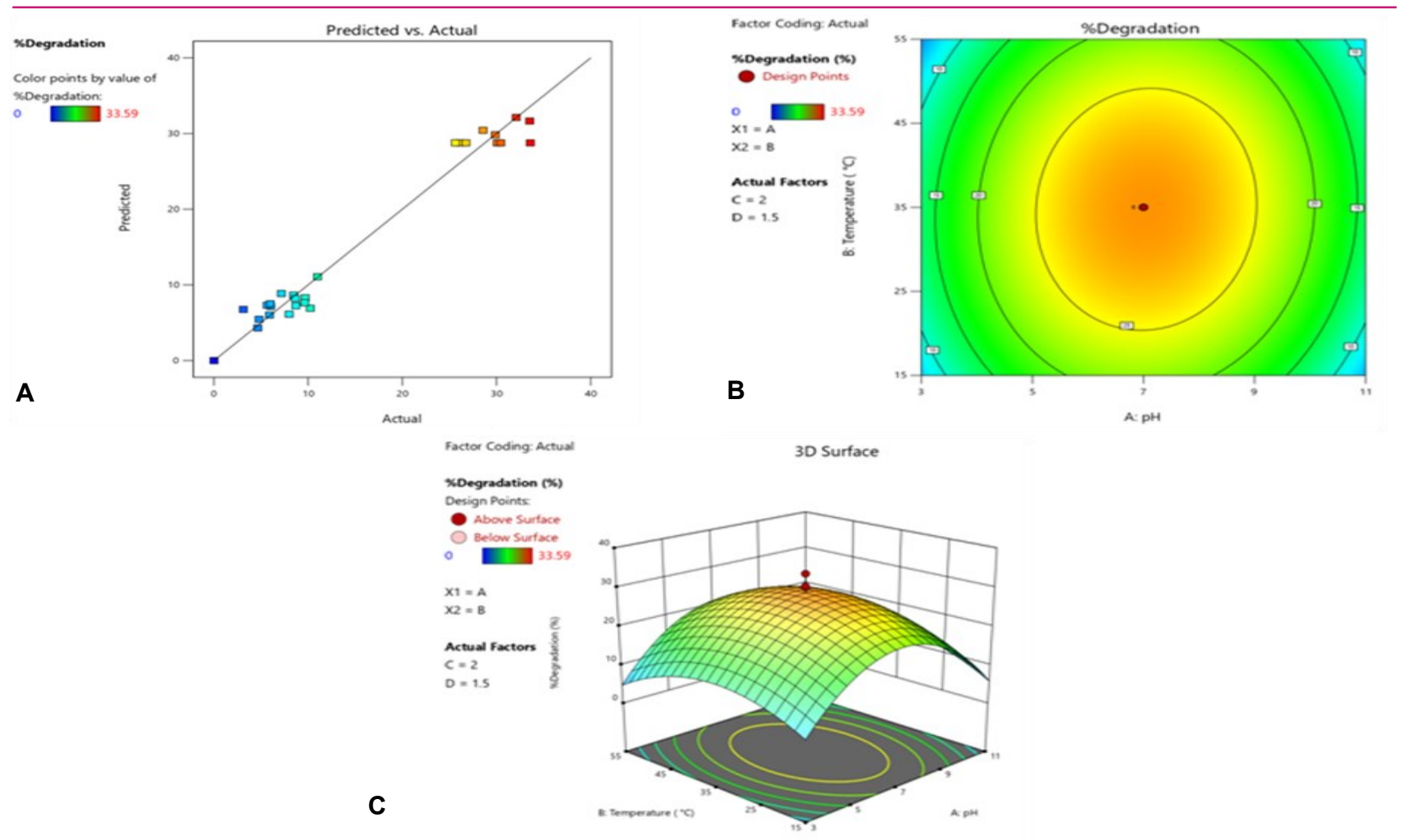

Fig. 3. The prediction versus actual plot $(A), 3 D$ plot $(B)$ and contour plot $(C)$ showing $\%$ Degradation of LDPE.
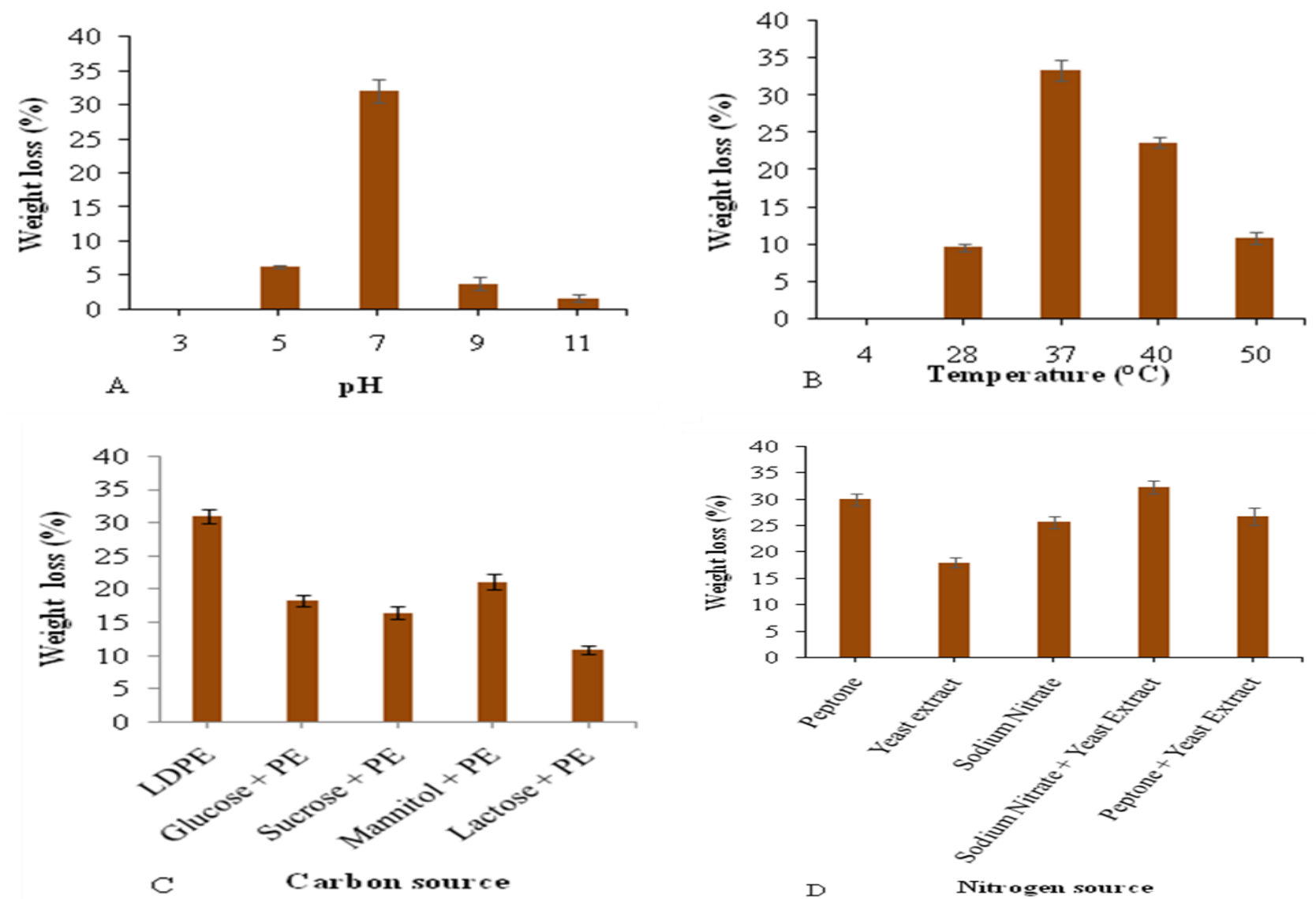

Fig. 4. Optimization of different growth parameters for the biodegradation activity of isolate SARR1 (A) pH (B) Temperature (C) Carbon sources and (D) Nitrogen sources. 
Rani, R. et al. / J. Appl. \& Nat. Sci. 13(2), 561 - 570 (2021)

Table 4. Analysis of variance (ANOVA) for quadric model by CCD of RSM for \% Degradation of LDPE optimizing growth by SARR 1 .

\begin{tabular}{lllllll}
\hline Source & $\begin{array}{l}\text { Sum of } \\
\text { Squares }\end{array}$ & df & $\begin{array}{l}\text { Mean } \\
\text { Square }\end{array}$ & F-value & p-value & \\
\hline Model & 3361.26 & 14 & 240.09 & 28.38 & $<0.0001$ & significant \\
A-pH & 2.65 & 1 & 2.65 & 0.3130 & 0.5861 & \\
B-Temperature & 0.5006 & 1 & 0.5006 & 0.0592 & 0.8119 & \\
C-Carbon & 7.92 & 1 & 7.92 & 0.9365 & 0.3523 & \\
D-Nitrogen & 2.23 & 1 & 2.23 & 0.2631 & 0.6173 & \\
AB & 13.38 & 1 & 13.38 & 1.58 & 0.2325 & \\
AC & 0.6440 & 1 & 0.6440 & 0.0761 & 0.7873 & \\
AD & 1.14 & 1 & 1.14 & 0.1347 & 0.7200 & \\
BC & 5.70 & 1 & 5.70 & 0.6737 & 0.4278 & \\
BD & 5.53 & 1 & 5.53 & 0.6541 & 0.4344 & \\
CD & 0.0564 & 1 & 0.0564 & 0.0067 & 0.9363 & \\
A $^{2}$ & 1090.93 & 1 & 1090.93 & 128.93 & $<0.0001$ & \\
$B^{2}$ & 598.45 & 1 & 598.45 & 70.73 & $<0.0001$ & \\
C $^{2}$ & 7.37 & 1 & 7.37 & 0.8711 & 0.3691 & \\
$D^{2}$ & 7.81 & 1 & 7.81 & 0.9229 & 0.3557 & \\
Residual & 101.53 & 12 & 8.46 & & & \\
Lack of Fit & 52.67 & 7 & 7.52 & 0.7698 & 0.6374 \\
Pure Error & 48.87 & 5 & 9.77 & & & \\
Cor Total & 3462.79 & 26 & & & & \\
\hline & & & & & & \\
& & & & & & \\
\end{tabular}

tween the OVAT and response with good accuracy and reliability. The F-value of Model 52.67 indicates that the model is significant. P-values obtained were less than 0.0500 implies model terms $\left(A^{2}, B^{2}\right)$ are significant. The non-significant lack of fit is suitable to fit the model. The estimation of coefficient represents the expected change in response per unit change in factor value when all remaining factors are held constant. As a rough rule indication, VIFs less than 10 are significantly tolerable (Table 5). The recent study evaluated the PLA food packaging degradation by Bacillus sp. SNRUSA4 by using RSM approach and obtained the BoxBehnken design for the optimization studies (Sawiphak and Wongjiratthiti, 2021).

\section{Optimization studies of isolate SARR1}

Effect of different $\mathrm{pH}$ on degradation efficiency of isolate SARR1

The effect of different $\mathrm{pH}$ values (3.0, 5.0, 7.0, 9.0, and $11.0)$ on the degradation efficiency of the isolate SARR1 was also studied. The $\mathrm{pH} 7.0$ was found the optimum $\mathrm{pH}$ for maximum degradation of LDPE and degraded $32.17 \pm 1.69 \%$ of LDPE (Fig. 4A). Similarly, B. amyloliquefaciens (Das and Kumar, 2015) and Thio- bacillus sp. and Clostridium sp. (Islami et al., 2019) showed maximum degradation of LDPE at $\mathrm{pH}$ 7.0.

\section{Effect of different temperatures on degradation effi-} ciency of isolate

The maximum LDPE degradation (33.52 $\pm 1.39 \%)$ was observed at $37^{\circ} \mathrm{C}$ by the bacterial isolate SARR1 within 30 days of incubation (Fig. 4B). The bacterium B. aryabhattai also showed $3.85 \pm 0.50 \%$ degradation at temperature $37{ }^{\circ} \mathrm{C}$ within 30 days of incubation (Hou et al., 2019). Similarly, $9 \%$ of degradation has been shown by Enterobacter cloacae AKS7 after 45 days of incubation at $30{ }^{\circ} \mathrm{C}$ (Sarker et al., 2020).

\section{Effect of different carbon sources on degradation efficiency of isolate}

The maximum LDPE degradation $(30.90 \pm 1.04 \%)$ was achieved by the isolate SARR1 was with polyethylene as a sole source of carbon while media amended with glucose + LDPE showed $18.31 \pm 0.90 \%$ and lactose + LDPE showed $10.92 \pm 0.64 \%$ degradation activity under optimized $\mathrm{pH} 7.0$ and temperature $\left(37^{\circ} \mathrm{C}\right)$ conditions (Fig. 4C). Similarly, a combination of glucose + LDPE in the media showed degradation of $7.13 \pm 0.05$ 
Rani, R. et al. / J. Appl. \& Nat. Sci. 13(2), 561 - 570 (2021)

Table 5. Response surface quadric model using ANOVA and its coeffiecient values.

\begin{tabular}{|c|c|c|c|c|c|c|}
\hline Factor & $\begin{array}{l}\text { Coefficient } \\
\text { Estimate }\end{array}$ & df & Standard Error & $95 \%$ Cl Low & 95\% Cl High & VIF \\
\hline Intercept & 28.76 & 1 & 1.19 & 26.18 & 31.35 & \\
\hline A-pH & 0.4069 & 1 & 0.7272 & -1.18 & 1.99 & 1.0000 \\
\hline B-Temperature & -0.1769 & 1 & 0.7272 & -1.76 & 1.41 & 1.24 \\
\hline C-Carbon & -0.5746 & 1 & 0.5938 & -1.87 & 0.7191 & 1.0000 \\
\hline D-Nitrogen & 0.3046 & 1 & 0.5938 & -0.9891 & 1.60 & 1.0000 \\
\hline$A B$ & 0.9144 & 1 & 0.7272 & -0.6701 & 2.50 & 1.0000 \\
\hline$A C$ & -0.2006 & 1 & 0.7272 & -1.79 & 1.38 & 1.0000 \\
\hline$A D$ & 0.2669 & 1 & 0.7272 & -1.32 & 1.85 & 1.0000 \\
\hline $\mathrm{BC}$ & -0.5969 & 1 & 0.7272 & -2.18 & 0.9876 & 1.0000 \\
\hline $\mathrm{BD}$ & 0.5881 & 1 & 0.7272 & -0.9963 & 2.17 & 1.0000 \\
\hline CD & -0.0594 & 1 & 0.7272 & -1.64 & 1.53 & 1.0000 \\
\hline$A^{2}$ & -15.26 & 1 & 1.34 & -18.19 & -12.33 & 1.39 \\
\hline$B^{2}$ & -7.28 & 1 & 0.8655 & -9.17 & -5.39 & 1.52 \\
\hline$C^{2}$ & 0.5542 & 1 & 0.5938 & -0.7395 & 1.85 & 1.11 \\
\hline$D^{2}$ & 0.5704 & 1 & 0.5938 & -0.7233 & 1.86 & 1.11 \\
\hline
\end{tabular}

$\%$ by $P$. fluorescens (Mukherjee et al., 2018). The isolates Staphylococcus sp. MMP10 and Bacillus sp. MGP1 also showed degradation activity of $2.08 \%$ and $2.92 \%$, respectively, with LDPE as a sole carbon source (Kunlere et al., 2019).

\section{Effect of different nitrogen sources on biodegrada- tion efficiency of isolate}

Under optimized $\mathrm{pH}$, temperature, and carbon sources, the isolate SARR1 showed maximum LDPE biodegradation of $32.32 \pm 1.16 \%$ in the presence of sodium nitrate and yeast extract. It was decreased (30.03 \pm $1.13 \%$ ) in the presence of peptone compared to sodium nitrate + yeast extract (Fig. 4D). Similarly, $P$. aeruginosa strain SKN1 (Nourollahi et al., 2019) and L. fusiformis (Mukherjee et al., 2016) showed degradation of $10.32 \pm 0.129 \%$ and $7.006 \pm 0.05 \%$, respectively in a medium amended with peptone. Whereas $6.975 \pm 0.05 \%$ LDPE degradation was achieved $\mathrm{NH}_{4} \mathrm{NO}_{3}$ as a nitrogen source in the media (Mukherjee et al., 2016). However, B. borstelensis degraded LDPE $11.0 \pm 0.1 \%$ in the presence of $\mathrm{KNO}_{3}$ as a nitrogen source (Hadad et al., 2005).

\section{Conclusion}

In the present scenario of globalization, more attention is needed for safe disposal of LDPE before its commercialization. In this study, an effective and eco-friendly degradation of LDPE using isolate SARR1 for 30 days developed substantial microbial degradation of LDPE. Moreover, the growth of SARR1 in the presence and absence of LDPE not only represented the adherence towards the surface but also showed the capability to utilize the LDPE strips within 30 days of incubation. The isolate represents cell-surface hydrophobicity that causes enhancement in the degradation of LDPE. The RSM analysis was used to optimize the media and degradation efficiency of LDPE. The prediction versus actual plot indicated the degradation rate of SARR1 was accurate. Based on the above studies, the isolate SARR1was selected for further research work. Furthermore, the isolate SARR1 can be used to study the cellular mechanisms for the utilization of complex carbon sources (LDPE). To study these mechanisms, genome sequencing with In Silico approach can be a useful tool for identifying the enzymes and their coding genes. To make effective commercialization of the isolate SARR1, the LDPE degrading microbial enzymes needs to be extracted and further characterized.

\section{ACKNOWLEDGMENTS}

The grant received from DST-SERB (EEQ/201 8/000892) to ARS is highly acknowledged. The author Ritu Rani acknowledges Maharshi Dayanand University, Rohtak, Haryana, India for University Research Scholarship. 
Rani, R. et al. / J. Appl. \& Nat. Sci. 13(2), 561 - 570 (2021)

\section{Conflict of interest}

The authors declare that they have no conflict of interest.

\section{REFERENCES}

1. Azzarello, M. \& Van Vleet, E. (1987). Marine birds and plastic pollution. Mar. Ecol. Prog. Ser., 37, 295-303. https://doi.org/10.3354/meps037295.

2. Balestri, E., Menicagli, V., Ligorini, V., Fulignati, S., Raspolli Galletti, A.M. \& Lardicci, C. (2019). Phytotoxicity assessment of conventional and biodegradable plastic bags using seed germination test. Ecol. Indic., 102, 569580. https://doi.org/10.1016/j.ecolind.2019.03.005

3. Bardají, D. K. R., Furlan, J. P. R. \& Stehling, E. G. (2019) Isolation of a polyethylene degrading Paenibacillus sp. from a landfill in Brazil. Arch. Microbiol., 201, 699-704. https://doi.org/10.1007/s00203-019-01637-9.

4. Bhatia, M., Girdhar, A., Tiwari, A. \& Nayarisseri, A. (2014). Nayarisseri, Implications of a novel Pseudomonas species on low density polyethylene biodegradation: an in vitro to in silico approach. Springerplus., 3. https:// doi.org/10.1186/2193-1801-3-497.

5. Das, M. P. \& Kumar, S. (2015). An approach to lowdensity polyethylene biodegradation by Bacillus amyloliquefaciens. 3 Biotech., 5, 81-86. https://doi.org/10.1007/ s13205-014-0205-1.

6. Emadian, S.M., Onay, T.T. \& Demirel, B. (2017) . Biodegradation of bioplastics in natural environments. Waste Manag., 59 ,526-536. https://doi.org/10.1016/j.wasma n.2016.10.006

7. Erni-Cassola, G., Wright, R. J., Gibson, M. I. \& ChristieOleza, J. A. (2019). Distribution of plastic polymer types in the marine environment; A meta-analysis. J. Hazard. Mater., 369, 691-698. https://doi.org/10.1016/j.jhazmat.20 19.02.067.

8. Eslami, H., Shariatifar, A., Rafiee, E., Shiranian, M., Salehi, F., Hosseini, S.S., Eslami, G., Ghanbari, R. \& Ebrahimi, A.A. (2019). Decolorization and biodegradation of reactive Red 198 Azo dye by a new Enterococcus faecalis-Klebsiella variicola bacterial consortium isolated from textile wastewater sludge. World J. Microbiol. Biotechnol., 35.

9. Esmaeili, A., Pourbabaee, A. A., Alikhani, H. A., Shabani, F. \& Esmaeili, E. (2013). Biodegradation of Low-Density Polyethylene (LDPE) by mixed culture of Lysinibacillus xylanilyticus and Aspergillus niger in Soil. PLOS One., 8. https://doi.org/10.1371/journal.pone.0071720.

10. Gajendiran, A., Krishnamoorthy, S. \& Abraham, J. (2016) Microbial degradation of low-density polyethylene (LDPE) by Aspergillus clavatus strain JASK1 isolated from landfill soil. 3 Biotech., 6,1-6. https://doi.org/10.1007/s13205-0160394-x.

11. Ghosh, S., Qureshi, A. \& Purohit, H. J. (2019). Microbial degradation of plastics: Biofilms and degradation pathways. Contam. Agric. Environ. Heal. Risks Remediat., 184 -199. https://doi.org/10.26832/aesa-2019-cae-0153-014.

12. Gilan, I., Hadar, Y. \& Sivan, A. (2004). Colonization, biofilm formation and biodegradation of polyethylene by a strain of Rhodococcus ruber. Appl. Microbiol. Biotechnol., 65,97-104. https://doi.org/10.1007/s00253-004-1584-8.

13. Hadad, D., Geresh, S. \& Sivan, A. (2005). Biodegradation of polyethylene by the thermophilic bacterium Brevibacillus borstelensis. J. Appl. Microbiol., 98,1093-1100. https:// doi.org/10.1111/j.1365-2672.2005.02553.x.

14. Hahladakis, J. N. \& lacovidou, E. (2019). An overview of the challenges and trade-offs in closing the loop of postconsumer plastic waste (PCPW): Focus on recycling. $J$. Hazard. Mater., 380. https://doi.org/10.1016/ j.jhazmat.2019.120887.

15. Harshvardhan, K. \& Jha, B. (2013). Biodegradation of lowdensity polyethylene by marine bacteria from pelagic waters, Arabian Sea, India. Mar. Pollut. Bull., 77,100-106. https://doi.org/10.1016/j.marpolbul.2013.10.025.

16. Hasan, F., Shah, A. A., Hameed, A. \& Ahmed, S. (2007). Synergistic effect of photo- and chemical treatment on the rate of biodegradation of low density polyethylene by Fusarium sp. AF4. J. Appl. Polym. Sci., 105,1466-1470. https://doi.org/10.1002/app.26328.

17. Hou, L., Xi, J., Chen, X., Li, X., Ma, W., Lu, J., Xu, J. \& Lin, Y.B. (2019). Biodegradability and ecological impacts of polyethylene-based mulching film at agricultural environment. J. Hazard. Mater., 378. https://doi.org/10.1016/ j.jhazmat.2019.120774.

18. Idowu, I. A., Atherton, W., Hashim, K., Kot, P., Alkhaddar, R., Alo, B. I. \& Shaw, A. (2019). An analyses of the status of landfill classification systems in developing countries: Sub Saharan Africa landfill experiences. Waste Manag., 87,761-771. https://doi.org/10.1016/j.wasman.2019.03

19. Islami, A. N., Tazkiaturrizki, T. \& Rinanti, A. (2019). The effect of $\mathrm{pH}$-temperature on plastic allowance for LowDensity Polyethylene (LDPE) by Thiobacillus sp. and Clostridium sp. J. Phys. Conf. Ser., https://doi.org/1 0.1088/1742-6596/1402/3/033003.

20. Jamal, M., Ahmad, W., Andleeb, S., Jalil, F., Imran, M., Nawaz, M. A., Hussain, T., Ali, M., Rafiq, M. \& Kamil, M.A. (2018). Bacterial biofilm and associated infections. J. Chinese Med. Assoc., 81,7-11. https://doi.org/10.1016/ j.jcma.2017.07.012.

21. Kumari, A., Chaudhary, D. R. \& Jha, B. (2019). Destabilization of polyethylene and polyvinylchloride structure by marine bacterial strain. Environ. Sci. Pollut. Res. 26,15071516. https://doi.org/10.1007/s11356-018-3465-1.

22. Kunlere, I. O., Fagade, O. E. \& Nwadike, B. I. (2019). Biodegradation of low density polyethylene (LDPE) by certain indigenous bacteria and fungi. Int. J. Environ. Stud., 76, 428-440. https://doi.org/10.1080/0020723 3.2019.1579586.

23. Mohee, R. \& Unmar, G. (2007). Determining biodegradability of plastic materials under controlled and natural composting environments. Waste Manag., 27,1486-1493. https://doi.org/10.1016/j.wasman.2006.07.023.

24. Mourad, A. H. I. (2010). Thermo-mechanical characteristics of thermally aged polyethylene/ polypropylene blends. Mater. Des., 31,918-929. https://doi.org/10.1016/j.mat des.2009.07.031.

25. Mukherjee, S., Chowdhuri, U. R. \& Kundu, P. P. (2016) Bio-degradation of polyethylene waste by simultaneous use of two bacteria: Bacillus licheniformis for production of bio-surfactant and Lysinibacillus fusiformis for biodegradation. RSC Adv.,6,2982-2992. https:// doi.org/10.1039/c5ra25128a.

26. Mukherjee, S., Roy Chaudhuri, U. \& Kundu, P. P. (2018). Biodegradation of polyethylene via complete solubilization 
by the action of Pseudomonas fluorescens, biosurfactant produced by Bacillus licheniformis and anionic surfactant. J. Chem. Technol. Biotechnol., 93,1300-1311. https:// doi.org/10.1002/jctb.5489.

27. Nourollahi, A., Sedighi-Khavidak, S., Mokhtari, M., Eslami, G. \& Shiranian, M. (2019). Isolation and identification of low-density polyethylene (LDPE) biodegrading bacteria from waste landfill in Yazd. Int. J. Environ. Stud., 76,236250. https://doi.org/10.1080/00207233.2018.1551986.

28. Novotný,Č. Malachová, K., Adamus, G., Kwiecień, M., Lotti, N., Soccio, M., Verney, V. \& Fava, F. (2018). Deterioration of irradiation/high-temperature pretreated, linear low-density polyethylene (LLDPE) by Bacillus amyloliquefaciens. Int. Biodeterior. Biodegrad., 132,259-267. https:// doi.org/10.1016/j.ibiod.2018.04.014.

29. Pathak, V. M. \& Kumar, N. (2017). Review on the current status of polymer degradation: a microbial approach. Bioresour. Bioprocess., 4. https://doi.org/10.1186/s40643-017 -0145-9.

30. Sarker, R. K., Chakraborty, P., Paul, P., Chatterjee, A. \& Tribedi, P. (2020). Degradation of low-density poly ethylene (LDPE) by Enterobacter cloacae AKS7: a potential step towards sustainable environmental remediation. Arch. Microbiol., 202,2117-2125. https://doi.org/10.1007/ s00203-020-01926-8.

31. Sawiphak, S. \& Wongjiratthiti, A. (2021). Optimisation of Culture Conditions for PLA food-packaging Degradation by Bacillus sp. SNRUSA4. Pertanika J. Sci. Technol., 29 (1).

32. Shah, A. A., Hasan, F., Hameed, A. \& Ahmed, S. (2008) Biological degradation of plastics: A comprehensive review. Biotechnol. Adv., 26,246-265. https:// doi.org/10.1016/j.biotechadv.2007.12.005.
33. Skariyachan, S., Manjunatha, V., Sultana, S., Jois, C., Bai, V. \&Vasist, K. S. (2016). Novel bacterial consortia isolated from plastic garbage processing areas demonstrated enhanced degradation for low density polyethylene. Environ. Sci. Pollut. Res., 23,18307-18319. https:// doi.org/10.1007/s11356-016-7000-y.

34. Sojak, L., Kubinec, R., Jurdakova, H., Hájeková, E. \& Bajus, M. (2006). High resolution gas chromatographicmass spectrometric analysis of polyethylene and polypropylene thermal cracking products. J. Anal. Appl. Pyrolysis., 78,387-399. https://doi.org/10.1016/j.jaap.2006.0 9.0 12.

35. Tokiwa, Y., Calabia, B. P., Ugwu, C. U. \& Aiba, S. (2009). Biodegradability of plastics. Int. J. Mol. Sci., 10,37223742. https://doi.org/10.3390/ijms10093722.

36. Vague, M., Chan, G., Roberts, C., Swartz, N. A. \& Mellies, J. L. (2019). Pseudomonas isolates degrade and form biofilms on polyethylene terephthalate (PET) plastic. BioRxiv., 647321. https://doi.org/10.1101/647321.

37. Whitman, W. B., Goodfellow, M., Kämpfer, P., Busse H.J., Trujillo M.E., Ludwig W., Suzuki, K. \& Parte A., (1984). Bergey's Manual of Systematic Bacteriology, Volume 5:The Actinobacteria. New York Springer, @2012. 1640f. http://books.google.com/books? id=66UMS7A2KisC\&pgis=1\%0Ahttp://www.springer.com/ life+sciences/book/978-0-387-95043-3.

38. Wolinska, A., Zapasek, M. \& Stepniewska, Z. (2016). The optimal TTC dose and its chemical reduction level during soil dehydrogenase activity assay. Acta Agrophys., 23.

39. Yang, H.S., Yoon, J.S. \& Kim, M.N. (2004). Effects of storage of a mature compost on its potential for biodegradation of plastics. Polym. Degrad. Stab., 84,411-417. https://doi.org/10.1016/j.polymdegradstab.2004.01.014. 